\title{
Gambaran Proses Komunikasi Dokter UGD dalam Timbang Terima Pergantian Jam Dinas di Rumah Sakit A
}

\section{Communication Model in Physician Handover at Emergency Room During Shift Change at " $A$ " Hospital}

\author{
Nofita Dwi $\mathrm{H}^{1}$, Indah Winarni', Arief Alamsyah $\mathrm{N}^{3}$ \\ ${ }^{1}$ Magister Manajemen Rumah Sakit Fakultas Kedokteran Universitas Brawijaya Malang \\ ${ }^{2}$ Fakultas IImu Budaya Universitas Brawijaya Malang \\ ${ }^{3}$ MLaboratorium Ilmu Kesehatan Masyarakat Fakultas Kedokteran Universitas Brawijaya Malang
}

\begin{abstract}
ABSTRAK
Komunikasi dalam proses timbang terima saat pergantian jam dinas dokter di Unit Gawat Darurat (UGD) merupakan periode kritis terhadap kontinuitas perawatan pasien.Walaupun telah diketahui bahwa komunikasi tersebutberperan penting dalam pencapaian keselamatan pasien, namun penelitian tentang proses tersebut, terutama di UGD masih sangat sedikit. Penelitian di salah satu rumah sakit swasta di Kabupaten Malang (yang selanjutnya disebut RS A)dilakukan pada kurun waktu Mei 2014 sampai dengan Juni 2014 untuk mendapatkan gambaran komunikasi dokter jaga UGD dalam proses timbang terima, permasalahan yang muncul dari komunikasi tersebut terkait tercapainya keselamatan pasien, serta solusi terhadap permasalahan tersebut. Penelitian ini menggunakan metode kualitatif, dengan melakukan pengamatan terhadap 6 proses timbang terima, wawancara terhadap 7 orang dokter jaga UGD, mempelajari dokumen yang terkait dengan timbang terima, serta diskusi dengan kelompok dokter jaga UGD RS A. Hasil penelitian menunjukkan bahwaproses komunikasi dokter jaga UGD di RS A saat timbang terima masih sangat beragam, tergantung dari dokter yang melakukan komunikasi. Ketidakseragaman bentuk komunikasi tersebut dapat menyebabkan kebingungan dokter akan rencana tindak lanjut pasien, sehingga berdampak pada terjadinya kesalahan medis. Diskusi dengan kelompok dokter jaga UGD didapatkan 3 penghalang pelaksanaan komunikasi efektif tersebut, yaitu: tidak ada standar yang digunakan dalam komunikasi timbang terima, tidak ada peraturan tentang timbang terima, dan perbedaan cara dokter berkomunikasi. Solusi awal yang dapat diberikan adalah dengan membuat lembar timbang terima dokter Jaga UGD RS A.
\end{abstract}

Kata Kunci: Keselamatan pasien, komunikasi, timbang terima, Unit Gawat Darurat

\begin{abstract}
Communication of physician handover during shift change in the emergency room (ER) is a critical period for the continuity of patient care. Although it has been known that communications in patient handover plays as important role achieving patient safety, but research on the process of patient handover in ER is limited. Research in one of the private hospitals in Malang (hereinafter referred to as RS A) conducted during the period May 2014 to June 2014 to get an overview of the ER physician communication in handover, the problems arising from the communication related patient safety achievement, as well as solutions to these problems. This study used a qualitative design, by observing 6 handover process, interview 7 ER physician, studying documents related to handover, as well as discussions with the ER physician group. The results of the interviews and observations showed that communication model during patient handover of ER physician is very varied. Heterogeneity of these communication model lead physician confusing on planning and patient follow-up that lead medical errors. Discussions with ER physician obtained 3 barrier implementation of effective communication: there is no standard that is used in communication in handover process, there are no rules about handover process, and differences characteristics of ER physician.
\end{abstract}

Keywords: Communication, handover, Emergency Room, patient safety

Jurnal Kedokteran Brawijaya, Vol. 28, No. 4, Agustus 2015; Korespondensi: Nofita Dwi H. Magister Manajemen Rumah Sakit Fakultas Kedokteran Universitas Brawijaya Malang, Jl. Veteran Malang Email: nofitayudha@gmail.com 


\section{PENDAHULUAN}

Standar akreditasi rumah sakit di Indonesia saat ini mengacu pada Joint Commission International (JCl), yang berfokus pada patient safety (keselamatan pasien). Pencapaian keselamatan pasien hingga saat ini dirasakan masih belum optimal karena masih tingginya angka kesalahan medis (medical errors) di berbagai fasilitas kesehatan. Hampir 1,3 juta kasus kesalahan medis terjadi setiap tahunnya, dengan 48.000 sampai 98.000 dari kasus tersebut mengakibatkan kematian pasien (1). Dari 25.000 sampai dengan 30.000 kejadian sentinel (sentinel event)di Australia yang seharusnya dapat dicegah, 11\% diantaranya disebabkan karena kegagalan komunikasi (2).

Komunikasi antar profesi di rumah sakit yang bertujuan untuk menjaga kelangsungan perawatan pada pasien terjadi sepanjang waktu perawatan. Salah satu komunikasi antar profesi di rumah sakit terjadi pada saat timbang terima pasien yang merupakan bentuk pengalihan tanggung jawab perawatan dan tanggung jawab medis pasien dari satu tenaga kesehatan ke tenaga kesehatan lainnya (2). Komunikasi selama proses timbang terima pasien merupakan periode kritis terhadap kontinuitas dan keberhasilan perawatan pasien. Proses timbang terima pasien yang buruk dapat menjadi faktor penyebab utama terjadinya kesalahan medis (medical errors) (3).

Salah satu timbang terima pasien terjadi saat pergantian jam dinas dokter di UGD. Walaupun telah diketahui bahwa komunikasi dalam timbang terima pasien memegang peran penting dalam keberhasilan pencapaian keselamatan pasien, namun penelitian tentang proses timbang terima pasien, terutama di UGD masih sangat sedikit (4). Rumah SakitA (RS A) adalah rumah sakit swasta tipe $D$ yang berada di Kabupaten Malang. RS A berdiri sejak November 2010. Dalam kurun waktu 4 tahun ini, trend kunjungan pasien di UGD RS A mengalami peningkatan. Semakin banyaknya jumlah pasien maka akan semakin banyak pula prosedur yang dikerjakan oleh dokter jaga UGD. Kondisi tersebut akan membuat beban kerja dokter menjadi tinggi. Tingginya beban kerja dokter dapat menyebabkan terjadi komunikasi yang tidak efektif di rumah sakit sehingga meningkatkan potensi kesalahan medis (medical errors) $(5,6)$.

Dalam upaya mendapatkan gambaran komunikasi dokter jaga UGD dalam proses timbang terima, permasalahan yang muncul dari komunikasi tersebut terkait tercapainya keselamatan pasien, serta solusi terhadap permasalahan tersebut perlu dilakukan kajian secara kualitatif. Hasil penelitian diharapkan dapat menjadi dasar dalam mengembangkan model komunikasi yang lebih efektif dalam proses timbang terima di UGD.

\section{METODE}

Penelitian dilakukan dengan metode kualitatif dengan cara melakukan observasi timbang terima, wawancara, studi dokumen yang terkait dengan timbang terima dan diskusi dengan kelompok dokter jaga UGD RS A mulai April 2014 sampai dengan Juni 2014. Subjek penelitian adalah 7 orang dokter yang bertugas di UGD RS A. Observasi dilakukan terhadap proses timbang terima pasien yang dilakukan pada setiap pergantian jam dinas dokter di UGD RS A yaitu pada pukul 07.00, 14.00, dan 20.00. Observasi proses tersebut dilakukan 1 jam sebelum waktu timbang terima, pada saat timbang terima, dan 1 jam setelah waktu timbang terima. Observasi dilakukan sebanyak 6 kali, yaitu 2 kali pada timbang terima pukul 07.00, 2 kali pada timbang terima pukul 14.00, dan 2 kali pada timbang terima pukul 20.00. Tujuan melakukan observasi adalah untuk melihat tanggung jawab dokter jaga UGD RS A, melihat proses komunikasi yang dilakukan oleh dokter jaga UGD saat timbang terima yang meliputi teknik komunikasi, waktu timbang terima, media, informasi yang disampaikan dalam komunikasi tersebut, serta dampak yang muncul setelah proses timbang terima tersebut.

Wawancara dilakukan kepada 7 orang dokter jaga UGD RS A dengan tujuan menggali informasi terkait pelaksanaan timbang terima serta permasalahan yang dirasakan dokter saat timbang terima. Disamping observasi dan wawancara dilakukan studi dokumen Hak dan Kewajiban Dokter Jaga UGD RS A serta dokumen Alur Pasien RS A yang bertujuan untuk mengetahui peraturan tentang tanggung jawab dokter jaga UGD RS A serta peraturan tentang timbang terima di RS A. Dokumen kepegawaian diperlukan untuk melengkapi informasi tentang latar belakang pendidikan dan pengalaman kerja dokter Jaga UGD RS A. Diskusi dengan kelompok dokter jaga UGD RS A dilakukan untuk mencari faktor penghalang komunikasi efektif dalam proses timbang terima serta solusi terhadap permasalahan yang muncul dari proses tersebut.

\section{HASIL}

\section{Proses Timbang Terima Dokter Jaga UGD RSA}

Studi data kepegawaian RS A menunjukkan bahwa pada periode April 2014 sampai dengan Mei 2014 tercatat ada 7 dokter yang bekerja sebagai dokter UGD RS A. Hasil studi dokumen Daftar Riwayat Hidup Dokter Jaga UGD RS A menunjukkan bahwa ketujuh dokter tersebut memiliki latar belakang pengalaman kerja dan pendidikan yang berbeda-beda. Seluruh dokter jaga UGD RS A belum pernah mengikuti pelatihan komunikasi efektif khususnya saat timbang terima. Observasi timbang terima, studi dokumen Alur Pasien di RS A serta dokumen Hak dan Kewajiban Dokter Jaga UGD RS A menunjukkan bahwa tanggung jawab dokter UGD RS A meliputi pemeriksaan seluruh pasien baru yang masuk UGD dan kamar bersalin, serta penanganan kegawatdaruratan pasien yang berada di ruang rawat inap. Berdasarkan hal tersebut area kerja dokter jaga UGD RS A meliputi UGD, kamar bersalin, dan ruang rawat inap.

Observasi (catatan 1) dan wawancara kepada dokter jaga UGD RS A memberikan gambaran bahwa komunikasi dokter jaga UGD RS A saat timbang terima dilakukan secara langsung. Dokter yang telah menjalankan tugasnya sebagai dokter jaga UGD (yang selanjutnya disebut dokter lepas dinas) akan bertatap muka dengan dokter yang akan menjalankan tugas sebagai dokter jaga UGD pada jam dinas selanjutnya (yang selanjutnya disebut dokter akan dinas).

\section{"disini dokter yang lepas dinas harus menunggu dokter yang akan dinas datang untuk melakukan timbang terima"}

Wawancara menunjukkan Dokter yang akan dinas harus menunggu dokter lepas dinas menyelesaikan tugasnya dalam menangani pasien untuk dapat bertatap muka, meskipun adakalanya dokter lepas dinas juga masih menunggu kedatangan dokter yang akan dinas. Kedua hal 
tersebut membuat waktu pelaksanaan timbang terima terlambat dari waktu yang dijadwalkan.

"disini biasanya timbang terima terlambat. Ratarata waktu pelaksanaan timbang terima mundur sekitar 30 menit dari berakhirnya jam dinas"

Dua catatan observasi berikut yang merekam informasi yang disampaikan dokter saat proses timbang terima menunjukkan bahwa informasi yang disampaikan dalam timbang terima masih sangat beragam, tergantung dari masing-masing dokter yang melakukan timbang terima.

"di kamar bersalin ada 2 pasien. pasien pertama dengan Gravida 1 dengan pembukaan 7-8, minta operasi."

"di ruang rawat inap atas ada pasien F, pasiennya dokter NL dengan dehidrasi. Sekarang ini sedang rehidrasi, matanya masih cowong, nanti jam 9 tolong dilihat lagi kondisi pasiennya dan laporkan perkembangan kondisi pasien ke dokter NL".

Penyebabnya ketidakseragaman informasi yang disampaikan adalah belum ada standar informasi yang dipakai dalam timbang terima yang berbentuk lembar timbang terima. Kadang-kadang dokter mencatat informasi yang ditimbangterimakan di selembar kertas, namun adakalanya dokter hanya menyampaikan informasi tersebut tanpa membuat catatan tertulis tentang informasi yang ditimbangterimakan. Rekaman wawancara berikut menunjukkan bahwa pemilihan penggunaan media dalam timbang terima masih tergantung dari dokter yang melakukan timbang terima. Jika jumlah pasien banyak, maka dokter akan membuat catatan tentang informasi yang ditimbang terimakan, namun jika jumlah pasien sedikit, dokter tidak membuat catatan karena merasa masih bisa menghafal.

"kalau jumlah pasiennya 3, atau lebih dari 3, biasanya informasi yang ditimbangterimakan ditulis, supaya tidaklupa."

" tapi kalau pasiennya hanya 1, kemudian hafal pasiennya, informasinya tidak ditulis pun juga tidak masalah."

\section{Dampak Komunikasi dalam Proses Timbang Terima Dokter Jaga UGD RSA}

Observasi timbang terima di RS A sebagaimana rekaman berikut menunjukkan bahwa ada permasalahan yang muncul setelah terjadinya komunikasi dalam proses timbang terima, yaitu dokter yang dinas masih terlihat kebingungan dalam melakukan tindak lanjut terhadap pasien yang sudah menjadi tanggung jawabnya walaupun telah melakukan timbang terima.

20.30: timbang terima malam itu dilakukan oleh dokter lepas dinas $(A D)$ dan dokter akan dinas (IR). Setelah melakukan timbang terima, IR menuju kamar bersalin dan berusaha menindaklanjuti informasi yang telah diperoleh dari $A D$. Sesampinya di kamar bersalin, IR terlihat membuka-buka Rekam Medis pasien sambil bertanya kepa bidan yang sedang dinas di kamar bersalin terkait informasi yang telah diperoleh saat timbang terima.

IR tampak menanyakan kepada bidan nama pasien baru yang tadi dioperkan oleh $A D$ dan rencana medis pasien tersebut.

Kebingungan dokter yang dinas tersebut dikarenakan informasi yang diperoleh saat komunikasi dalam proses timbang terima kurang jelas. Hal itu menyebabkan dokter harus membaca ulang rekam medis pasien atau bertanya terlebih dahulu kepada bidan atau perawat yang sedang dinas tentang kondisi pasien tersebut. Kebingungan yang dialami dokter jaga UGD RS A akan membuat dokter membutuhkan waktu lebih lama untuk memutuskan pemberian terapi kepada pasien. Kondisi tersebut dapat mengancam keselamatan pasien. Wawancara dengan dokter jaga UGD RS A menyebutkan pengalaman dokter jaga UGD RS A tentang insiden keselamatan pasien di RS A yang disebabkan karena komunikasi yang kurang efektif saat timbang terima.

Solusi Terhadap Permasalahan Timbang Terima Dokter Jaga UGD RSA

Permasalahan yang muncul dalam proses timbang terima dokter jaga UGD RS A dikarenakan proses komunikasi dokter jaga UGD di RS A saat timbang terima masih sangat beragam, tergantung dari dokter yang melakukan komunikasi. Hasil diskusi dengan kelompok dokter jaga UGD RS A diidentifikasi ada 3 penghalang pelaksanaan komunikasi yang efektif saat timbang terima dokter jaga UGD di RS A.Penghalang pertama adalah belum ada standar informasi yang harus disampaikan pada proses timbang terima. Standar informasi tersebut dapat dibuat dalam bentuk lembar timbang terima. Tidak adanya lembar timbang terima, membuat informasi yang disampaikan sangat beragam tergantung masing-masing dokter yang berkomunikasi.

"Kalau menurut saya yang standar dok..coba kalau ada standarnya pastibisajalan.."

"..mungkin bisa dibuat seperti itu..biar informasinya juga seragam apa saja yang harus disampaikan."

Penghalang kedua adalah tidak ada peraturan terkait penggunaan lembar timbang terima sebagai media dalam mencatat informasi yang ditimbang terimakan.

\section{"..belum tentu standar dalam bentuk lembar timbang terima ini jalan kalau tidak ada peraturan yang mengharuskan dokter untuk mengisinya atau membuatnya"}

Penghalang ketiga adalah karakteristik dokter yang memiliki perbedaan cara berkomunikasi yang disebabkan karena perbedaan latar belakang pendidikan, pengalaman, dan miskinnya keterampilan berkomunikasi.

"ada buku timbang terimanya, ada peraturannya, tapi kalau dokternya tidak dapat menyampaikan informasi yang ada di buku tersebut, maka kondisinya akan tetap seperti sekarang" 


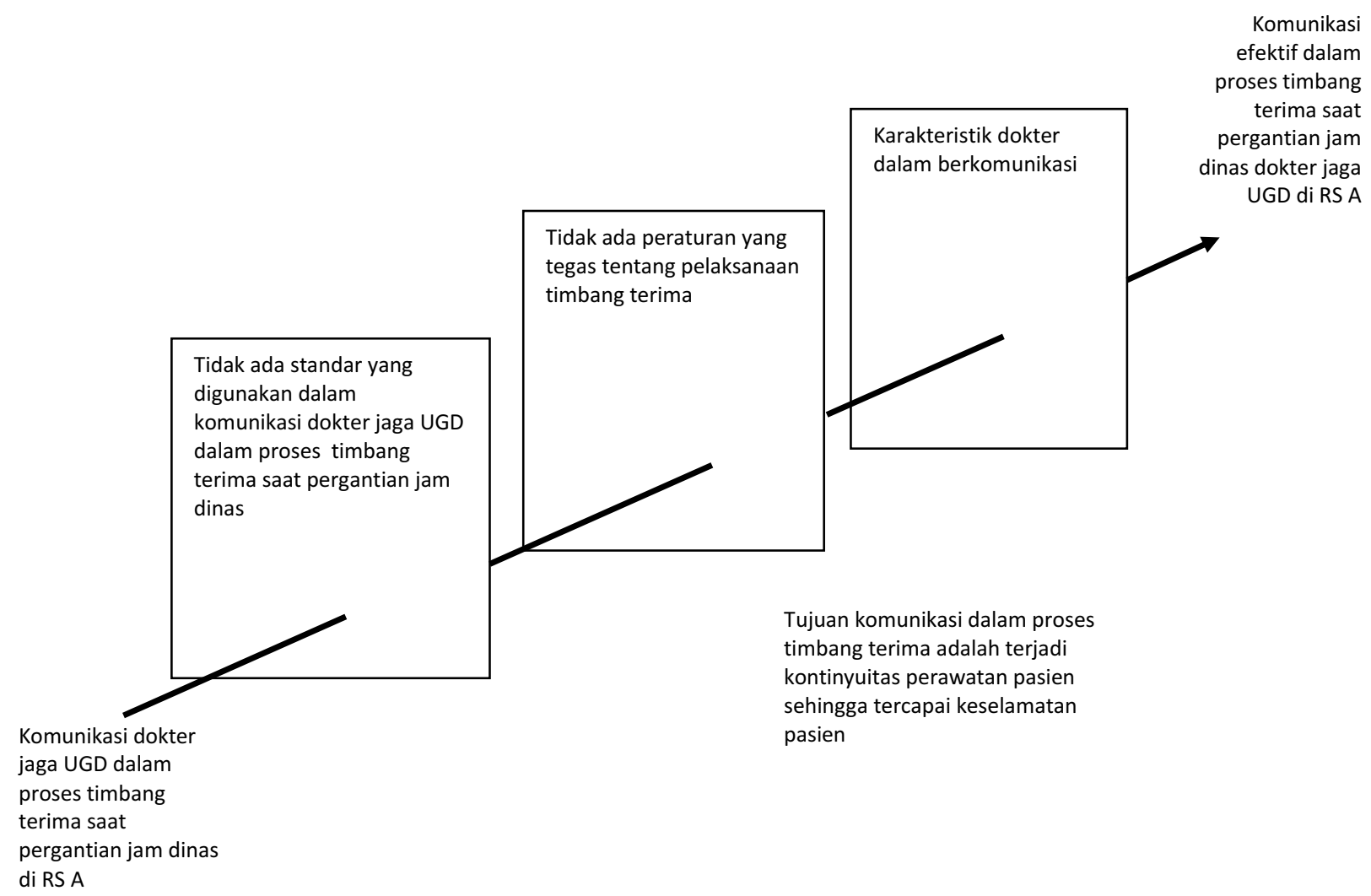

Gambar 1. Faktor penghalang komunikasi efektif dalam proses timbang terima

"ya..perbedaan karakter dokter dalam berkomunikasi yang bisa dikarenakan perbedaan pengalaman yang diperoleh"

Ketiga penghalang tersebut jika digambarkan dapat menjadi lembaran-lembaran penghalang tercapainya komunikasi efektif dalam proses timbang terima saat pergantian jam dinas dokter di UGD.

Dari ketiga penyebab tidak tercapainya komunikasi efektif dalam timbang terima dokter jaga UGD RS A, maka dibuat solusi terhadap permasalahan tersebut. Solusi awal yang dapat dibuat adalah membuat standar timbang terima.

\section{DISKUSI}

Keberhasilan pelaksanaan timbang terima saat pergantian jam dinas dokter di UGD dipengaruhi oleh berbagai faktor. Penelitian ini melengkapi pernyataan dari penelitian sebelumnya yang menyebutkan ada 6 faktor paling sering menghambat komunikasi di rumah sakit (5), yaitu: hirarki rumah sakit yang mencekam sehingga dapat membuat karyawan takut untuk berkomunikasi, budaya masing-masing profesi yang berbeda satu sama lain, penyampaian informasi tentang kasus pasien yang tidak akurat saat proses perpindahan pasien, tinggin.ya beban kerja individu yang berkomunikasi, konflik interpersonal, dan tidak memahami peran masing-masing individu dalam sebuah tim. Timbang terima pasien didefinisikan sebagai bentuk transfer tanggung jawab perawatan dan tanggung jawab medis pasien dari satu tenaga kesehatan ke tenaga kesehatan lainnya (2). Tujuan dari timbang terima pasien adalah terjadi komunikasi antar profesi kesehatan terkait informasi spesifik tentang pasien, sehingga dapat memastikan terbentuknya lingkungan kerja yang aman dan efektif secara terus menerus demi tercapainya kontinuitas perawatan pasien (4).

\section{Gambaran Proses Timbang Terima Dokter Jaga UGD RS A}

Timbang terima saat pergantian jam dinas dokter di UGD RS A dilakukan oleh dokter dokter jaga UGD yang lepas dinas dan dokter yang akan dinas. Seluruh dokter jaga UGD RS A tersebut memiliki latar belakang pengalaman kerja dan pendidikan yang berbeda-beda. Perbedaan latar belakang pendidikan dan pengalaman yang dimiliki oleh dokter jaga UGD RS A akan membuat perbedaan cara dokter dalam berkomunikasi. Latar belakang seorang dokter tersebut akan mempengaruhi kepercayaan diri yang tumbuh dalam diri dokter tersebut untuk berkomunikasi (7). Perbedaan cara dokter dalam berkomunikasi dapat menjadi salah satu defisiensi dalam berkomunikasi. Defisiensi dalam komunikasi dapat berujung pada terjadinya kesalahan medis (8). Seluruh dokter jaga UGD RS A belum pernah mendapatkan pelatihan komunikasi terutama komunikasi dalam timbang terima. Kondisi tersebut membuat dokter miskin keterampilan dalam berkomunikasi, sehingga dapat memperburuk pelaksanaan komunikasi dalam proses timbang terima. Komunikasi efektif dalam proses timbang terima memerlukan landasan pendidikan dan keterampilan tentang komunikasi (4).

Tanggung jawab dokter jaga UGD RS A meliputi pemeriksaan seluruh pasien yang baru masuk UGD dan kamar bersalin, serta penanganan kegawatdaruratan pasien yang berada di ruang rawat inap. Luasnya area kerja dokter jaga UGD RS A membuat beban kerja dokter jaga UGD RS A sangat tinggi. Salah satu faktor penghambat komunikasi efektif di rumah sakit adalah tingginya beban 
kerja individu yang berada di rumah sakit tersebut, karena beban kerja yang tinggi dan juga keterbatasan waktu yang ada untuk berkomunikasi akan memicu kondisi stress pada individu. Kondisi tersebut akan membuat komunikasi berlangsung dengan terburu-buru dan informasi yang disampaikan tidak akurat. Penyampaian informasi yang tidak akurat dapat membahayakan pasien (5).

Komunikasi dokter jaga UGD RS A dalam proses timbang terima dilakukan secara langsung. Dokter lepas dinas akan bertatap muka dengan dokter akan dinas untuk menyampaikan informasi-informasi seputar kondisi medis pasien yang diperlukan (9). Ada berbagai cara untuk melakukan timbang terima saat pergantian jam dinas tenaga kesehatan. Salah satunya adalah tenaga kesehatan yang lepas dinas bertatap muka dengan tenaga kesehatan yang akan dinas untuk melakukan komunikasi verbal (10). Proses komunikasi dengan bertatap muka adalah cara terbaik yang bisa dilakukan untuk bentuk komunikasi verbal, karena dapat menciptakan ruang interaksi antara komunikator dan komunikan. Komunikator dan komunikan dapat saling bertanya untuk mengklarifikasi informasi yang disampaikan (11).

Dokter yang akan dinas harus menunggu dokter lepas dinas menyelesaikan tugasnya dalam menangani pasien untuk dapat bertatap muka, meskipun adakalanya dokter lepas dinas juga masih menunggu kedatangan dokter yang akan dinas. Kedua hal tersebut membuat waktu pelaksanaan timbang terima terlambat dari waktu yang dijadwalkan. Keterlambatan waktu timbang terima akan membuat waktu pelaksanaan timbang terima semakin terbatas. Terbatasnya waktu untuk berkomunikasi dapat membuat tekanan individu dalam berkomunikasi akan semakin besar. Hal tersebut dapat membuat individu menjadi terburu-buru dalam berkomunikasi, sehingga akan membuat informasi yang disampaikan dalam timbang terima menjadi kurang akurat. Penyampaian informasi seputar kondisi medis pasien yang kurang akurat dapat membahayakan keselamatan pasien (5).

Informasi yang disampaikan dalam timbang terima masih sangat beragam, tergantung dari masing-masing dokter yang melakukan timbang terima. Penyebab ketidakseragaman informasi yang disampaikan dalam timbang terima adalah belum adanya standar informasi yang dipakai dalam timbang terima yang berbentuk lembar timbang terima. Salah satu faktor yang mempengaruhi keberhasilan proses timbang terima pasien saat terjadi pergantian jam dinas dokter di UGD adalah adanya struktur yang digunakan dalam proses timbang terima pasien (3). Standar tentang struktur yang jelas tentang komunikasi dapat mengarahkan keberhasilan dalam komunikasi (5). Timbang terima sebaiknya dilakukan dengan komunikasi langsung yang dilengkapi dengan penulisan informasi tersebut dalam sebuah media untuk meminimalisir dampak yang tidak diharapkan dari komunikasi dan menghilangkan asumsiasumsi dari informasi yang disampaikan. Rekomendasi untuk timbang terima saat pergantian jam dinas dokter di UGD adalah bentuk komunikasi verbal dan tertulis yang dilakukan secara bersama-sama (9). Ketidakseragaman informasi yang disampaikan tersebut menyebabkan komunikasi tidak akurat. Penyampaian informasi tentang kasus pasien yang tidak akurat saat proses perpindahan pasien seringmenghambatkeberhasilan komunikasi di rumah sakit. Supaya komunikasi efektif, maka informasi yang disampaikan harus komplit, jelas, tegas, dan tepat waktu (5).

\section{Dampak Komunikasi dalam Proses Timbang Terima Dokter Jaga UGD RSA}

Ada permasalahan yang muncul yang dirasakan oleh dokter yang dinas, yaitu: dokter merasa bingung dengan tugas yang akan dilakukan sehingga dapat memperlama waktu dokter dalam menanggapi keluhan pasien. Telah diketahui bahwa buruknya timbang terima pasien yang terjadi saat pergantian jam dinas dokter di UGD akan berakibat pada terjadinya pelayanan kesehatan yang tidak adekuat, seperti pengulangan pemeriksaan kepada pasien, pembuangan waktu dalam penanganan pasien, keterlambatan disposisi dan penanganan pasien, kebingungan dalam penanganan pasien, dan kejadian tidak diharapkan (adverse event) (4). Kebingungan dokter jaga UGD RS A terhadap tugasnya terkait dengan penatalaksanaan pasien dapat menjadi faktor resiko terjadinya kesalahan medis (4). Salah satu pengalaman dokter jaga UGD RS A menyatakan bahwa telah terjadi kesalahan medis terhadap pasien di ruang rawat inap berupa ketidaksesuaian tatalaksana pasien dikarenakan informasi yang kurang lengkap saat timbang terima. Proses timbang terima pasien pada saat pergantian jam dinas dokter di UGD menjadi salah satu prosedur yang paling beresiko tinggi atas kejadian kesalahan medis (medical errors) di rumah sakit (3).

\section{Penghalang Proses Timbang Terima Dokter Jaga UGD RS A}

Diskusi kelompok dengan dokter UGD RS A dilakukan dengan tujuan untuk mencari penyebab dari dampak yang muncul setelah komunikas dokter jaga UGD dalam proses timbang terima. Menurut dokter jaga UGD RS A terdapat 3 penghalang komunikasi efektif dalam proses timbang terima tersebut. Penghalang pertama adalah tidak ada standar yang digunakan dalam timbang terima yang dapat membuat keseragaman informasi dalam timbang terima. Standar tentang struktur yang jelas tentang komunikasi dapat mengarahkan keberhasilan dalam komunikasi (5). Salah satu faktor yang mempengaruhi keberhasilan proses timbang terima pasien saat terjadi pergantian jam dinas dokter di UGD adalah adanya struktur yang digunakan dalam proses timbang terima pasien (3).

Penghalang kedua tercapainya komunikasi efektif adalah belum ada peraturan tentang pelaksanaan timbang terima, yang meliputi waktu pelaksanaan timbang terima, penggunaan standar dalam timbang terima, serta bentuk reward and punishment dalam pelaksanaan timbang terima. Tidak adanya peraturan tentang pelaksanaan timbang terima dapat menjadi salah satu penghalang tercapainya komunikasi efektif di sebuah rumah sakit (). Pelaksanaan timbang terima masih tergantung dari masing-masing dokter yang melaksanakan timbang terima. Menurut Myers ketika organisasi tidak dapat mengakomodir perbedaan gaya komunikasi yang dimiliki oleh masing-masing individu, maka hal tersebut dapat menjadi defisiensi dalam komunikasi yang berdampak pada terjadinya kesalahan medis (12).

Penghalang ketiga tercapainya komunikasi efektif dalam timbang terima adalah perbedaan cara dokter dalam berkomunikasi. Perbedaan cara berkomunikasi antar dokter dapat menjadi salah satu defisiensi dalam berkomunikasi (9). Perbedaan cara dokter dalam berkomunkasi bisa disebabkan karena minimnya keterampilan dokter dalam berkomunikasi serta 
kepribadian masing-masing dokter. Minimnya keterampilan dokter berkomunikasi dapat disebabkan karena kurang pelatihan komunikasi, latar belakang pendidikan dan pengalaman dokter. Minimnya panduan pendidikan praktis dalam timbang terima pasien menyebabkan perbedaan cara berkomunikasi dokter dalam timbang terima (9).

Keberhasilan pelaksanaan komunikasi dokter jaga UGD RS A dalam proses timbang terima saat pergantian jam dinas dipengaruhi oleh berbagai faktor. Tidak semua faktor penghalang komunikasi efektif di rumah sakit dari penelitian pendahulu ditemukan di RS A, tetapi gambaran komunikasi dokter jaga UGD RS A dalam proses timbang terima saat pergantian jam dinas dokter seperti yang tersebut di atas dapat membuat celah untuk terjadinya komunikasi yang tidak efektif. Dalam penelitian sebelumnya disebutkan bahwa faktor penghalang komunikasi di sebuah rumah sakit adalah: adanya hirarki rumah sakit yang mencekam, adanya perbedaan budaya masing-masing profesi di rumah sakit, penyampaian informasi tentang kasus pasien yang tidak akurat,

\section{DAFTAR PUSTAKA}

1. Keller SM. Effects of Extended Work Shifts and Shift Work on Patient Safety, Productivity, and Employee Health. American Association of Occupational Health Nurses. 2009; 57(12): 497-502.

2. Payne CE, Stein JM, Leong T, and Dressler DD. Avoiding Handover Fumbles: AControlled Trial of AStructured Handover Tool Versus Traditional Handover Methods. British Medical Journal Quality \& Safety. 2012; 21(11): 925-932.

3. Farhan $\mathrm{M}$, Brown $\mathrm{R}$, Woloshynowych $\mathrm{M}$, Vincent $\mathrm{C}$. The ABC of Handover: A Qualitative Study to Develop a New Tool for Handover in the Emergency Department. Emergency Medicine Journal. 2012; 29(12): 941-946.

4. Ye K, McD Taylor D, Knott JC, Dent A, and MacBean CE. Handover in the Emergency Department: Deficiencies and Adverse Effects. Emergency Medicine Australasia. 2007; 19(5): 433-441.

5. Bendaly L and Bendaly N. Improving Healthcare Team Performance. Canada: John Willey\&Sons; 2012. tingginya beban kerja individu, konflik antar personal, serta ketidakpahaman individu atas perannya di rumah sakit (5). Ringkasan penghalang komunikasi saat timbang terima dokter jaga UGD di RS A adalah: adanya adanya perbedaan budaya masing-masing profesi yang akan mempengaruhi individu dalam berkomunikasi, penyampaian informasi tentang kasus pasien yang tidak akurat, tingginya beban kerja individu yang berkomunikasi, tidak ada standar yang dapat mengarahkan informasiinformasi yang harus ditimbang, tidak ada peraturan yang mengarahkan pelaksanaan timbang terima, serta karakteristik dokter jaga UGD RSMD yang membuat komunikasi tidak efektif

Keterbatasan dalam penelitian ini adalah perubahan jumlah subjek penelitian selama kurun waktu penelitian dilakukan. Hal tersebut menyebabkan diskusi dengan kelompok dokter jaga UGD RS A tidak dapat dilakukan dengan seluruh subjek penelitian.Setelah penelitian ini, saran yang dapat diberikan kepada RS A adalah membuat peraturan tentang timbang terima sehingga terjadi keseragaman pelaksanaan timbang terima.

6. Foster S and Manser T. The Effects of Patient Handoff Characteristics on Subsequent Care: A Systematic Review and Areas for Future Research. Academic Medicine. 2012; 87(8): 1105-1124

7. Lloyd M and Bor R. Communication Skills for Medicine. London: Churchill Livingstone Elsevier; 2009.

8. Myers S. Patient Safety and Hospital Accreditation. New York: Springer Publishing Company; 2012.

9. Solet DJ, Norvell JM, Rutan GH, and Frankel RM. Lost in Translation: Challenges and Opportunities in Physician-to-Physician Communication During Patient Handoffs. Academic Medicine. 2005; 80(12): 10941099.

10. Patterson ES, Roth EM, Woods DD, Chow R, and Gomes JO. Handoff Strategies in Settings with High Consequences for Failure: Lessons for Health Care Operations. International Journal for Quality in Health Care. 2004; 16(2): 125-132.

11. Mistry NK, Toulany A, Edmonds JF, and Matlow A. Optimizing Physician Handover Through the Creation of a Comprehensive Minimum Data Set. Healthcare Quarterly. 2010; 13: 102-109. 